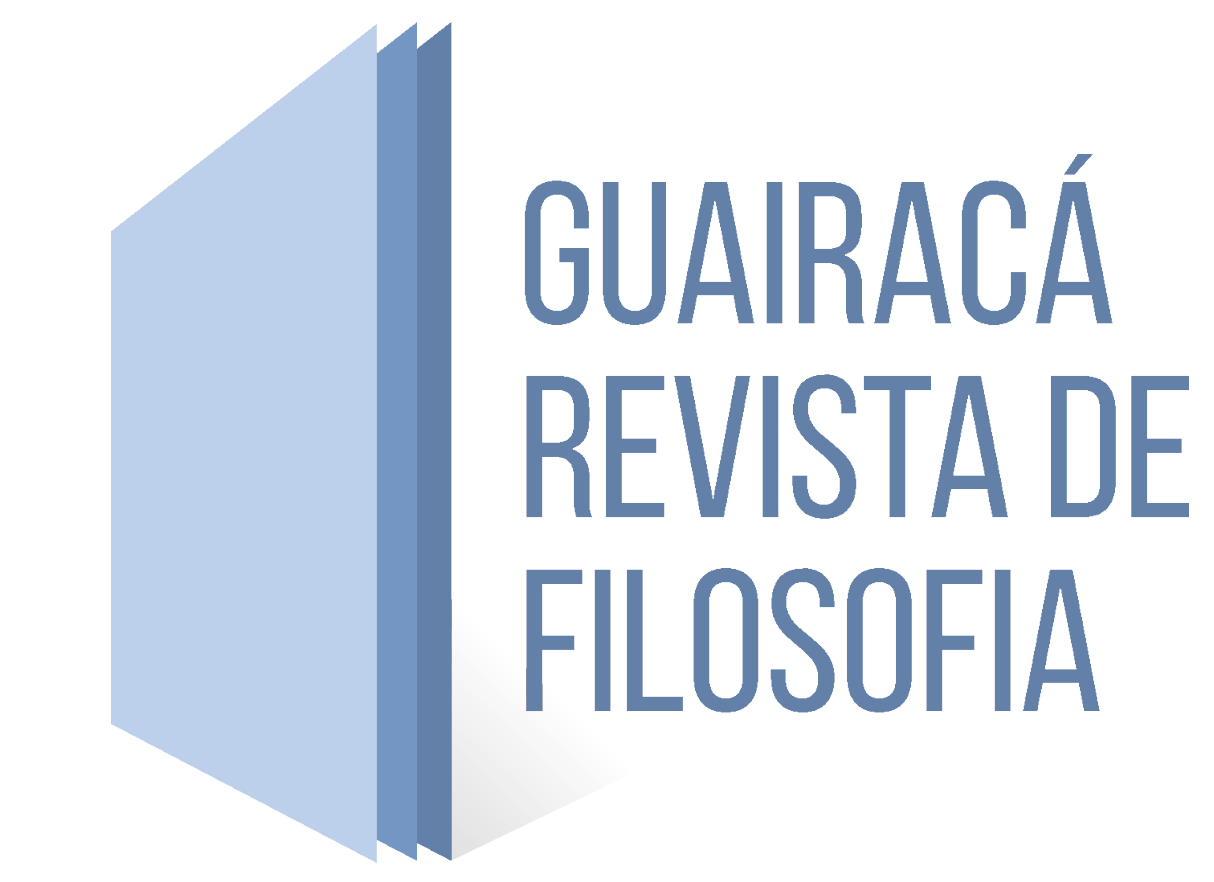

\title{
O MAL E A CONVERSÃO EM A RELIGIÃO NOS LIMITES DA SIMPLES RAZÃO DE KANT
}

DLLSONBRITODA ROCHA KATIA SMONEVILLANOVA²

Resumo: Nosso interesse neste ensaio centra-se no enfrentamento engendrado por Immanuel Kant (1724-1804) da problemática que gira em torno do mal e da conversão, uma das empreitadas fulcrais no panorama geral de seu investimento filosófico. Grosso modo, em A Religião nos Limites da Simples Razão, obra de sua autoria, datada de 1793, sobre a qual nos debruçaremos, ele assegurará que o mal origina no próprio homem, tendencioso ao vício, dado o desregramento interior. Todavia, devido os ditames da razão, sua égide, é impelido à direção contrária, chamando-o à conversão, seja na esfera moral, seja na religiosa, visto a possibilidade de coadunação das áreas, ressalvadas as devidas peculiaridades, e ao fato de que a religião não pode se furtar ao compromisso proeminentemente moral. Ocorre, pois, que perante o mal, tratado por Kant não como uma espécie de entidade real e ontológica, como se dá no maniqueísmo, ad exemplum, o filósofo proporá categoricamente a conversão (retorno, reforma) ao bem como sendo um caminho de via única a ser buscado livremente e de maneira ininterrupta pelo homem.

Palavras-chave: Mal, conversão, moral, religião.

1. Mestre em Filosofia pela UNESP/Marília, mestre em Teologia pela Pontificia Università Gregoriana (PUG), Roma, Itália, docente universitário nas Faculdades Integradas de Bauru (FIB). E-mail: dilsondarocha@hotmailcom

2. Bacharel e Licenciada em Psicologia pela Universidade do Sagrado Coração (USC), pós-graduada em Psicologia Analítica pela PUC/SP e psicóloga clínica. E-mail: ksvillanova@hotmail.com 


\section{THE EVIL AND CONVERSION IN RELLGION ON THE LIMTS OF THE SIMPLE REASON OF KANT}

Abstract: Our interest in this essay focuses on the confrontation engendered by Immanuel Kant (1724-1804) of the problematic that revolves around evil and conversion, one of the central tasks in the general panorama of his philosophical investment. Roughly, in The Religion on the Limits of Simple Reason, a work of his own, dated 1793, on which we shall be concerned, he will assert that evil originates in man himself, tendentious to addiction, given inner selflessness. However, because of the dictates of reason, its aegis is impelled to the opposite direction, calling it to conversion, whether in the moral sphere or in the religious sphere, considering the possibility of coadunition of the areas, with due regard to the peculiarities, and to the fact that religion can not steal from a prominent moral commitment. It occurs, therefore, that in the face of evil, treated by Kant not as a kind of real and ontological entity, as in Manichaeism, ad exemplum, the philosopher will categorically propose the conversion (return, reformation) to the good as being a road the only one to be sought freely and uninterruptedly by man.

Keywords: Evil, conversion, moral, religion.

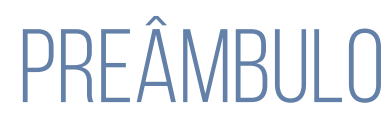

A questão do mal em $A$ Religião nos Limites da Simples Razão ${ }^{3}$, trabalho suntuoso no estudo sobre a religião, que percorreremos neste ensaio, é encarada de maneira positiva, visto que Kant imprime confiança na conversão do homem, tendo este sempre a oportunidade de retornar ao princípio bom. ${ }^{4}$ Ocorre que o homem não poucas vezes se afasta do imperativo moral, todavia, para nosso filósofo o retorno ao bem é possível, o que explica seu jeito esperançoso de enfrentar a problemática relativa ao mal, quando investirá, sem reservas de forças, na liberdade de escolha, significando que o sujeito deve deliberar entre as opções.

No momento em que o homem se afasta das máximas das Lei Moral seu coração torna-se perverso. Mas pelo fato do imperativo moral apenas ter sido ofuscado pela fraqueza de ânimo e impureza do coração humano, a realização do Bem ainda deve ser possível. Isto porque o Mal Radical é pensado por Kant enquanto malum defectus

3.Doravante A Religião.

4.Para uma melhor compreensão desta temática cf. GIACÓIA, O. "Reflexões sobre a noção de mal radical", In: Studia Kantiana, v. 1, (1998), p. 183-202. 
da faculdade de desejar. O Mal Radical não é um malum privationis. Ainda que exista uma propensão para o Mal na natureza humana, o princípio Bom não é impedido de acontecer, visto que sua realização é um ideal nobre e que o dever ordena, portanto, possível de realizar. O mal é decorrência de uma perversão do uso da liberdade, porque o imperativo da Moralidade apenas foi ofuscado, mas não desapareceu. (FREIRE, 2005, p. 115, grifo nosso).

Spinelli (2013) alude que tal possibilidade se justifica em vista de dois grandes pontos: i. por um lado, a disposição para o bem é originária (o que significa que o bem é mais ancestral e característico da natureza humana do que o mal); ii. por outro, a lei moral permanece enquanto um móbil secundário, o que implica que ela foi perdida e deve ser reconquistada, mas, apenas, que o homem deve restituir a sua genuína relevância. Tornar-se bom, contanto, quer significar aderir a lei moral enquanto móbil supremo para o seguimento das máximas. (cf. p. 136). Desta sorte, é passível de aferição que Kant está seguindo sua construção moral, ${ }^{5}$ quando deposita no homem a responsabilidade pelas suas ações, ao que advoga o protagonismo do sujeito. De posse disso inferimos que, também quando este se corrompe, tal ato é de sua autoria e não de outrem.

A questão do mal é desenvolvido em $A$ Religião a fim de formular sua tese acerca do Mal Radical (Radikale Böse), Kant parte da constatação de que a vontade dos homens não se encontra, em inúmeras ocasiões, subordinada aos ditames da Lei Moral. Isto ocorre porque há um conflito entre sensibilidade e razão. Afirmar que o Mal é fruto de uma perversão do uso do arbítrio significa que o homem é o seu único responsável. Em A Religião Kant afirma que o Mal é Radical, pois se encontra enraizado à natureza da espécie humana. "O homem é mal por natureza significa tanto como: Isto se aplica a ele considerado na sua espécie." Acrescenta que o Mal é radical porque "corrompe o fundamento de todas as máximas." (FREIRE, 2005, p. $114)$.

Verifica-se no corpus kantiano que o homem não poderá ter outra motivação para agir senão a lei da boa vontade, que é reivindicada também no campo religioso, sob condição de um aparato sacro. Kant não descrê no homem; confia que ele possa se voltar às boas ações, ${ }^{6}$ bem como aposta que pode se disciplinar nesta direção. Quando ele afirma que o homem é mal por natureza, o faz no sentido hermenêutico

5. Tanto é verdade que está de acordo com sua construção moral, que na Fundamentação se lê: "Só pode ser objeto de respeito e, portanto, mandamento aquilo que está ligado à minha vontade somente como princípio e nunca como efeito, não aquilo que serve à minha inclinação mas o que domina ou que, pelo menos, a exclui do cálculo na escolha, quer dizer a simples lei por si mesma. Ora, se uma ação realizada por dever deve eliminar totalmente a influência da inclinação e com ela todo o objeto da vontade, nada mais resta à vontade que a possa determinar do que a lei objetivamente, e, subjetivamente, o puro respeito por esta lei prática, mesmo com prejuízo de todas as minhas inclinações." (p. 31).

6. A fim de uma investigação sobre o retorno ao bem ou reforma de caráter cf. MUNZEL, J. F. Kant's Conception of Moral Character. Chicago: The University Press, 1999, p. 74. 
de que tem uma propensão (pendo) radical para o mal e, a fortiori, que é capaz de reformar o caráter.

\begin{abstract}
Ele não reconhece a fonte de tal maldade nas inclinações, tampouco afirma que o homem elege a própria oposição à lei enquanto móbil. Daí que a restauração do bem não implica numa resistência ou abnegação frente às inclinações, mas numa disciplina das mesmas a partir da qual a lei moral se imponha como móbil suficiente para seguimento das máximas. (SPINELLI, 2013, p. 136).
\end{abstract}

Neste robusto projeto engendrado por Kant, a propensão ao mal em nós resume a questão do mal, sua originalidade; ${ }^{7}$ porém, a possibilidade da conversão não é um sistema hermético, mas um programa viabilizável. "Esta propensão existe em nós e permite explicar temporariamente o mal como provindo da preexistência em nós desta própria propensão; esta explicação, contudo, não retira nada à validade da explicação racional do mal pela liberdade." (RENAUD, 1993, p. 528). Kant insiste de que mesmo com tal propensão o ser humano, por isso mesmo, busca a virtude. "Kant sustenta que nossa busca da virtude sempre começa de um estado de imperfeição moral ou, conforme ele diz nos seus escritos tardios, de uma condição de "mal radical", uma propensão a fazer escolhas contrárias à lei moral." (WOOD, 2009, p. 483). Já no atinente a "transmissão hereditária do pecado", ele destoa da teologia clássica, entendendo-a como absurda, e em seu lugar perpetra a concepção da inclinação ao mal, que paulatinamente vai se incorporando em A Religião.

Seja como for que a origem do mal moral no homem possa estar constituída, entre todos os modos de representação da sua difusão e continuação através de todos os membros da nossa espécie e de todas as gerações, o mais inconveniente é representa-lo como chegado a nós a partir dos primeiros pais por herança (...). (KANT, 1992, p. 45, grifo nosso).

Decerto, não se trata de o mal ser ontologicamente fazedor de parte da natureza humana, antes, deve ser empreendido como sendo uma questão estritamente antropológica. Pois bem, o mal (ou, se quisermos, pecado) não pode estar na natureza (= carne) do homem, como que, exempli gratia, numa hipóstase, já que se assim o fosse, a liberdade ficaria comprometida. (cf. KLEMME, 2013, p. 35). Para Kant, o homem, também em quesitos religiosos, a fim de não entrar em contradição com a moral, tem a liberdade de fazer a opção pelo bem, e de dizer não às ações más, uma vez que ele é determinado pela vontade pura. O mal para ele é o "não agir com base nas máximas que possam ser elevadas a leis universais." Neste afã, Freire (2005) entende que o talhamento que Kant estabelece neste sentido se deve ao fato da defesa da liberdade do homem. Ou seja, se o homem estivesse condenado ao bem por um lado, ou ao

7. Para um exame apurado acerca da originalidade do mal para Kant cf. CORREIA, A. O conceito de mal radical. Trans/Form/Ação, v. 28, n. 2, p. 83-94, 2005. 
mal, por outro, ele não teria a possibilidade da escolha, o que aponta para um ato rigorosamente de liberdade e não de outro gênero, como aquele de estofo quiméricometafísico, ao qual Kant endereça, de maneira declarada, duras críticas.

Assim, dois princípios coexistem no ser humano: uma propensão (Hang) para o Mal e uma disposição (Anlage) para o Bem. Os acontecimentos históricos levaram Kant a admitir que o homem tendeu a desenvolver a propensão para o Mal em lugar da disposição para o Bem. Desenvolveu esta propensão justamente pelo fato de ser livre, porque também lhe era dada a possibilidade da disposição para o Bem. Se o homem tornou-se mal segundo sua livre escolha, isto não significa que não tenha por fim fazer prevalecer o Bem, visto que este é o fim mais nobre à que ele deve se propor. (p. 115).

\section{PANORAMAGERAL}

Para Kant a pessoa não é, ontologicamente, determinada para o bem ou para o mal, pelo contrário, ela pode, dado a liberdade, optar por obedecer ou não a boa conduta. O princípio do mal existe na natureza humana, mas também o princípio do bem, evidentemente não havendo passividade nesta convivência. Todo homem tem a possibilidade da boa conduta, já que este é dotado de liberdade. (cf. DINIS, 1993, p. 498-499). Justamente, o fato do mal não ser assimilado de maneira ontológica na natureza humana, mas antropológica, explica a veracidade lógica da asserção kantiana de que o homem tem a liberdade de escolha, de que todos dispomos.

O ato bom como o ato mau não provêm da "natureza" do homem se se entender por isso uma estrutura ontológica outra que não a liberdade. Mas dado que a liberdade em Kant é transcendental, ela escapa ao campo dos fenômenos observáveis. Se o mal proviesse de uma natureza em nós diferente da liberdade, o mal não poderia ser-nos imputado e não seria o mal. (RENAUD, 1993, p. 518).

É tarefa do homem obedecer a boa conduta, esforçando em tudo para fazê-lo. E aqui pode somar, caso alguém necessite, o contributo singular da religião, sempre indigitando para o bem. "O esforço por tal conduta de acordo com a lei moral, que não é espontânea, postula a necessidade da religião, e abre a possibilidade do triunfo do bem sobre o mal, da obediência à lei moral sobre a desobediência à mesma lei." (DINIS, 1993, p. 499). Kant vai distinguir ainda que quando se fala da corrupção do homem, isso acontece não em sua natureza, mas como um acometimento das máximas, de modo que o homem é livre para não se deixar corromper, como assinala Renaud: 
Não existe também uma corrupção da natureza no homem, mas sim das suas máximas; tal corrupção depende da liberdade humana. Diremos nos termos da teologia clássica que o pecado original não implica uma corrupção da "natureza" humana; a liberdade deve, portanto ter a possibilidade de se restaurar a partir de si próprio. (1993, p. 518).

Kant elenca que, uma vez o homem não sendo apenas um sujeito racional, se fazem presentes as três "disposições", a saber: I. para a animalidade, visto que é um ser vivo; II. para a humanidade, em virtude de que é um ser vivo e racional; e por fim, III. para a personalidade, uma vez que tem a faculdade de determinar seu arbítrio." (cf. RENAUD, 1993, p. 520). Segundo nosso filósofo, elas são boas e são originalmente disposições para o bem, pelo fato de estarem ligadas a natureza humana. A inclinação para o mal moral é contingente ao ser, diferentemente da disposição que os seres humanos possuem para o bem. A disposição para o bem, por ser ligada com a natureza humana, é necessária. Neste entendimento, fazer o bem é natural como outra necessidade, ao passo que fazer o mal é uma opção, isto é, o homem pode escolher. O bem, entendido como necessário, está acessível a todos por meio da razão, enquanto que o mal, entendido como contingente, é possível de ser superado pela natureza humana. Para Kant, nos homens há paixões e inclinações e, de quando em vez, as pessoas são afetadas pela fraqueza de vontade (cf. ALLISSON, 200, p. 58). Todavia, ressalva ele, as inclinações não são absolutas e, depois, através da razão é possível superar os desvios que levam ao mal moral. A despeito de suas inclinações, o que impera absolutamente no ser humano é a razão, conditio sine qua non para discernir. Assim sendo, torna-se possível achar o caminho para a superação do mal. Porém, o caminho não deve ser buscado fora do agente (heteronomia), mas em sua condição racional, em sua própria estrutura. Portanto, precisa ficar claro que: “Esta declaração significa que 1) Kant aceita que a propensão para o mal é já presença do mal; 2) que a propensão para o mal é moral e não natural (sendo esta afirmação já contida na precedente); 3) que não é possível explicar tal fato." (RENAUD, 1993, p. 524).

Poder-se-ia assinalar que as ações humanas podem ser orientadas por móbeis (Triebfeder), e motivos (Bewegungsgrund), o que é perceptível tanto na Fundamentação quanto na obra em exame, A Religião. No que toca as inclinações, o ser humano é influenciado, mas não determinado a agir conforme inclinações. A determinação depende da incorporação ou adoção das inclinações em máximas, que então se tornam móbeis. Kant é contra a liberdade de indiferença, uma vez que o ser humano tem a liberdade de escolher algo diferente, todavia, essa liberdade tem que ser contrastada com a liberdade de indiferença. 
Uma vez Kant pertencendo, ainda que com uma postura crítica, ao Pietismo, ${ }^{8}$ teve acesso ao relato bíblico-genesiano acerca do ocorrido na narrativa simbólica da criação (Gn 1,1-31), envolvendo as personagens Adão e Eva, no tangente à sedução, todavia, isso não aniquila seu pensamento acerca da disposição para o bem, sempre investindo na mudança de mentalidade e de atitudes no ser humano, ou seja, há sempre a alternativa de converter-se. (cf. RENAUD, 1993, p. 529). Não há uma condenação da natureza humana ao mal, pois o que se corrompe na natureza, segundo ele, é tão somente a propensão para o mal, de modo que a disposição para o bem é incorruptível, sendo a natureza do homem igualmente incorrupta. " "Em Kant não se pode falar globalmente de uma corrupção da natureza humana." (RENAUD, 1993, p. 531). A responsabilidade pelo mal é do ser humano, não podendo este culpar algo exterior, pois, segundo Kant o homem tem a liberdade de escolher uma alternativa diferente da propensão ao mal, quer dizer, fazer optação pelo bem. Assim, ele retira da natureza do homem a pertença ontológica ao mal, sendo o mal uma eleição do próprio homem, e ele mesmo deve assumir a responsabilidade por não optar pelo bem ou protelar a referida escolha, por falta de coragem, próprio da menoridade.

A exegese kantiana acerca do pecado original relatado na epístola paulina dirigida aos romanos (Rm 5,12-21) é crucial, não comungando da interpretação dada por Paulo de Tarso e posteriormente por Agostinho de Hipona (354-430) e pela Patrologia. Como acenamos, Kant não admite a ideia bíblico-patrística de que herdamos o pecado de um primeiro pai, ${ }^{10}$ mas que o mal existe no homem como que uma propensão para. Neste tocante, certamente Kant tinha presente a problemática da heresia de Pelágio da Bretanha (360-435), refutada pelos Padres da Igreja, que não nos interessa nesta feita. De todo modo, em Kant temos que:

A referência que Kant faz ao pecado original é interessante: a propensão para o mal é dita peccatum originarium ("a propensão para o mal é portanto ato no primeiro sentido peccatum originarium"). Kant, que recusa a tese dogmática da transmissão hereditária do pecado original (originans), apropria-se desta expressão para a referir ao ato inteligível da propensão para o mal e qualifica de "peccatum derivatum" ou vício o ato mau materialmente posto (...) Pois, não se trata na verdade do análogo do pecado original. Seria o caso se Kant admitisse que a humanidade inteira tivesse sido maculada pela culta do primeiro homem, mas ele recusa precisamente isso. (RENAUD, 1993, p. 524).

Há um entendimento kantiano específico acerca do pecado original, ao que fala de inclinação, perversidade, corrupção etc., numa linguagem peculiar, a fim

8. Tendo em vista uma meticulosa aferição no que concerne à relação de Kant com o movimento pietista cf. MARTINS, E. C. R. Crusius e Kant. Revista Portuguesa de Filosofia, v. 50, n. 1/3, p. 253-260, 1994.

9. A respeito da temática da "propensão para o mal" e "disposição para o bem" cf. PAVÃO, A. "Filosofia da religião e mal radical em Kant". In: Kant e-prints, série 2, v. 2, n. 2, 2007, p. 171-179.

10. Tal doutrina pode ser confrontada também em: 1Cor 15, 22; Sl 51. 
de significa-lo de tal forma que destoa da hermenêutica engenhada pela Tradição teológica judaico-cristã. Tal peculiaridade interpretativa pode ser aclarada no enxerto que segue:

A malignidade (vitiositas, pravitas) ou, se preferir, o estado de corrupção (corruptio) do coração humano, é a inclinação do arbítrio para máximas que compõem o móbil dimanante da lei a outros (não morais). Pode igualmente chamar-se a perversidade (perversitas) do coração humano, porque invertem a ordem moral a respeito dos móbiles de um livre arbítrio e, embora assim possam ainda existir sempre ações boas segundo a lei (legais), o modo de pensar é, no entanto, corrompido na sua raiz (no tocante a intenção moral), e o homem é, por isso, designado como mal. (KANT, 1992, p. 36).

Cimino (2015) identifica uma problemática, que atinge à tradição teológica, no que tange à hermenêutica do pecado original, conflitando-a com aquela kantiana.

(...) O mal radical, do modo como Kant o concebe é o peccatum originarium o qual é, ao mesmo tempo, o fundamento de todo ato contrário à lei (peccatum derivativum). Como fica, então, esse peccatum originarium diante do pecado original da tradição cristã, cuja fonte é a narração da queda de Adão e Eva, narrada no livro do Gênesis? (p. 61).

Kant nos adverte que, muito embora tenhamos a nosso dispor a lei como máxima de nossas ações morais, devemos atinar para o princípio do mal que sempre está ao lado, ali próximo, ao que nos exorta a lutarmos sempre contra o mal, ancorados na razão, da qual dispomos. "11 "Mas nem por isso deixa de estar sempre exposto aos assaltos do princípio do mal; e a fim de afirmar sua liberdade, que é constantemente atacada, deve doravante manter-se sempre preparado para a luta." (KANT, 1992, p. 99). Spinelli (2013) nos ajuda a entender a diferenciação kantiana entre o que ele chama de "dicotomia" a partir dos termos "disposição" e "propensão". Vejamos:

O homem, do ponto de vista moral, apesar de ser disposto para o bem, está imerso no mal [Böse]. Kant trata do conceito de mal no interior de uma dicotomia reconhecida por ele na natureza humana. Tal dicotomia é traduzida através dos conceitos antagônicos de disposição para o bem [Anlage zum Guten] e propensão para o mal [Hang zum Bösen] (...) Neste sentido, a própria propensão para o mal não se constitui ainda no mal radical, assim como a disposição para o bem não representa ainda o bem consumado. Tudo depende do modo como o homem maneja a lei da moralidade no processo de adoção do móbil para a execução da ação. (p. 134).

11. Quanto a isso cf. WEIL, E. "Le mal radical, la religion et la morale". In: Problèmes Kantiens. 2a. ed. ed. revista e aumentada. Paris: Vrin, 1990, p. 37-63. 
A comunidade ética é o lugar ideal para se fazer tal mudança. ${ }^{12}$ Pois bem, esta comunidade seria fundada e guiada pela virtude, que por sua vez contrapõe às paixões e inclinações. Esta comunidade se difere da sociedade civil jurídica que, segundo Kant não é capaz de erradicar o mal, naquilo referente à perversidade, não obstante ele enxergue que seja necessária. Sucede que para ele, o mal será extirpado quando o homem se inserir na comunidade. Tanto na esfera individual quanto na jurídica isso não acontecerá. O recinto coletivo instigará os indivíduos, que buscam o mesmo fim, a se afastarem do mal, sendo a comunidade ética o locus onde as pessoas conseguem desvencilhar-se do mal. Esta comunidade surge com o dever comum do gênero humano em buscar erradicar seus males. $O$ mal enfrentado nas adversidades não representa o ser humano em sua inteireza. Cumpre, pois, consumar a superação do mal através da comunidade ética, onde os agentes, pari passu, dotados de razão, estabelecem a organização da vida social.

Kant dispensa um bocado de fôlego para discorrer sobre a necessidade de transformação ou reforma do caráter (conversão), sem o que o homem não consegue ser moral. "Assim no homem que, apesar da corrupção de seu coração, guarda ainda a boa vontade, permanece a esperança de um retorno ao bem, do qual se afastou." (KANT, 1992, p. 40). Não seria exagerado enunciar que a conversão é a porta de entrada por onde os fiéis aderem a uma religião. “Não é a partir de uma compreensão de Deus que se tem acesso à religião, mas a partir da problemática da conversão." (RENAUD, 1993, p. 515). Evidentemente, Kant une moral e religião com o intento de fazer com que o homem se converta, isto é, acolha os modelos contidos na religião a fim de que o fiel, seguindo-os como arquetípicos, possam superar o mal. Nosso filósofo faz isso, verbi gratia, quando toma a figura do crido Messias como podendo ser seguido, já que é uma espécie de ideal, pertencente ao campo simbólico-religioso e moral, a ser vivido, sem receio de restringi-lo a tal âmbito.

\begin{abstract}
Mas se o Mal não pode ser extirpado da natureza humana, todavia, cabe ao homem superá-lo. Kant aponta a Religião enquanto via para esta superação. A Religião deve unir-se à Moral a fim de não se tornar um modo de solicitar favores. Pois bem, Kant toma Jesus Cristo enquanto arquétipo da perfeição moral. Todavia, adverte que mesmo sendo Cristo a personificação de uma vontade santa deve ser pensado por nós como um preceito a seguir e não a imitar. A ideia de perfeição moral é uma ideia da razão. Portanto, o arquétipo da moralidade deve ser procurado em nossa razão prática. A figura de Cristo serve apenas como estímulo em busca da adequação entre as ações e a Lei Moral. (FRERE, 2005, p. 116).
\end{abstract}

12. Para um estudo minucioso relativamente a comunidade ética recomendamos recorrer à obra em exame "A Religião", em sua 3- parte, como também SPINELLI, L. M. Kant e o Sumo Bem comunitário. Ethic@, Florianópolis, v. 11, n. 1, p. 37-57, 2012. 
A mudança terá de ser não somente de pensamento, mas também dos atos, sempre rumando para o bem e numa constante reforma pessoal, que se dá de maneira paulatina, sendo a conversão um percorrer constante e que mira o bem. (cf. KANT, 1992, p. 53). Este itinerário não se esgota, mas se estende por toda a existência. (cf. KANT, 1992, p. 82). O retorno ao bem deve se dá em qualquer dimensão da vida, mas isso deve acontecer não simplesmente como uma obediência a uma lei externa ou heterônoma (legal), mas no sentido moral autônomo. "Assim, o intemperante retorna à moderação por amor de sua saúde, o mentiroso à verdade para recuperar sua honra, o injusto à probidade por amor da tranquilidade ou do ganho. Ora, tornar-se um homem bom não só legalmente, mas também moralmente (agradável a Deus)." (KANT, 1992, p. 43). Kant usa uma linguagem peculiar para abordar da conversão, mas por outro lado não deixa de se valer, o que lhe era próximo, das Escrituras, e nos aconselha a tomar a linguagem bíblica, para dizer que o homem deve despir-se do homem velho e vestir-se do novo. Para tanto, é imprescindível morrer para o pecado. (cf. KANT, 1992, p. 64). ${ }^{13}$ Quando Kant fala de uma espécie de regeneração, a fim de tornar-se um homem novo, e como atesta João 3,5 (perícope tomada com afinco por Kant), deve haver uma nova criação, naquele sentido do homem se tornar cada vez melhor, como num progresso constante, tendo um endereçamento certeiro: do mal para o bem. (cf. KANT, 1992, p. 43). Ele é incisivo quanto a tomada da imagem da narrativa neotestamentária do homem novo:

\begin{abstract}
Quando o homem inverte o fundamento supremo das suas máximas, pelas quais era um homem mau, graças a uma única decisão imutável (e se reveste assim de um homem novo), é nessa medida, segundo o princípio e o modo de pensar, um sujeito susceptível do bem, mas só no contínuo agir e devir será um homem bom. (KANT, 1992, p. 53).
\end{abstract}

Kant toma a mudança de comportamento empregando, dentro de uma coerência, a moral aos preceitos religiosos, como sendo um mandamento de fato. Neste sentido temos que:

\begin{abstract}
Efetivamente, não obstante a queda, ressoa sem diminuição na nossa alma o mandamento: devemos tornar-nos homens melhores; devemos, portanto, também poder fazê-lo, inclusive se o que conseguimos fazer houvesse de por si só ser insuficiente e nos tornássemos assim apenas susceptíveis de uma assistência superior para nós imperscrutável. (KANT, 1992, p. 51).
\end{abstract}

Uma vez que há a transgressão, precisa acontecer o retorno à retidão, isso em matéria de moral. Já naquilo que atina a religião, a transgressão da lei moral enquanto

13. Na perícope bíblica Rm 6, 10 pode ser encontrado este pensamento, onde se lê: "Pois, quanto a ter morrido, de uma vez morreu para o pecado (...)." 
mandamento divino é o que é alcunhado de pecado, dentro de uma linguagem onde se adapta ou se parafraseia a moral, versando a partir de termos condizentes com a religião. Equivale a um preceito onde a religião precisa ser um espelho da moral, devendo de modo necessário refleti-la, a propósito de sua viabilidade. É nesta exigência que Kant assegurará que a moral pode levar à religião, mas que a religião não pode prescindir de forma alguma da moral (cf. KANT, 1992, p. 63). Contanto, converter é mudar da disposição má para a disposição boa. Importava a Kant que o adepto de uma religião deveria ser ciente de que a conversão deve ser um esforço do homem mesmo, não transferindo (delega, tutela) tal função a outra pessoa, nem tampouco a Deus. “(...) o melhoramento moral do homem é um negócio que compete ao próprio homem." (KANT, 1992, p. 78). Para ele, quem vai imperar esta obrigação, preceituando o imperativo moral, o dever, será a própria razão, intrínseca ao homem.

A razão, legisladora moral, além das leis que prescreve a todo indivíduo, iça ainda uma bandeira da virtude, sinal de reunião para todos aqueles para os quais o bem é caro, a fim de que se reúnam em torno dele e o levem a vencer, acima de qualquer coisa, o mal que os ataca sem trégua. (KANT, 1992, p. 83).

Entendemos que Kant realiza uma mudança metodológico-moral, quando propõe uma questão nem sempre tratada a contento, ou seja, não é pelo fato da pessoa, para nos valer de um exemplo peculiar, no caso do fiel, frequentar o chamado "sacramento da reconciliação" que a partir daí se tornará virtuoso, mas o que faz a pessoa agir boamente é a prática das virtudes. “(...) o bom caminho não conduz da remissão dos pecados à virtude, mas precisamente o contrário, da virtude à remissão dos pecados." (KANT, 1992, p. 181). Implica que o homem precisa ter o cuidado devido, a fim de que não caia na indolência moral, a lassidão de caráter. Para tanto, necessita desvencilhar das "armadilhas" do princípio mal e sem protelar tal revolução ou delegar para algo fora dele mesmo. Há que manter viva a esperança de que seja possível o retorno ao bem, não deixando que aquela propensão ao mal aniquile a disposição ao bem. Retornar ao bom princípio é o significado que Kant vai conferir ao tema da conversão, tendo um teor acentuadamente moral, antes mesmo de qualquer sistema ou doutrina religiosa.

O seu significado [conversão] é estritamente moral, na medida em que para ocorrer a conversão é necessário que a disposição originária para o bem não tenha sido aniquilada pela propensão para o mal, ou seja, é preciso que exista a possibilidade do restabelecimento da "pureza moral" do indivíduo (...) Kant salienta que a virtude pode ser adquirida através de uma revolução da disposição de ânimo. Essa aquisição perpassa pela esperança que resta ao homem de buscar melhorar, sob o ponto de vista moral, mediante a fundação de um caráter. (CALOVI, 2008, p. 49-51). 
Nesta empreitada pode entrar o papel da "religião da razão"14 de incitar aqueles que creem ao esforço que devem fazer para que ocorra o retorno conversivo ao bem. Cabe a ela fazer constantemente a promoção da moralidade. Ela tem o dever de fazer com que os homens se tornem melhores. Pois, como assegura Caetano (2015), "O fito principal de uma religião positiva é tornar os homens melhores." (p. 12). Todavia, precisa atenção para não inverter os papeis, pois Kant insiste que é função intransferível do próprio homem fazer acontecer o que ele chama de revolução, tendo o significado de ir ao encontro do bem, acatando-o.

A revolução é um acontecimento interno da consciência que decide sair do mal para ao bem. Uma revolução na disposição de ânimo significa que um propósito firme e inabalável de seguir a lei moral, que foi assumida nas máximas, é o fundamento do esforço posterior e sincero para cumprir o dever. (CAETANO, 2015, p. 73).

O método interpretativo moral do qual Kant se serve para ler as Escrituras tem um propósito conversivo plausível. "Com efeito, a própria leitura dessas Escrituras sagradas ou o estudo de seu conteúdo tem por finalidade tornar os homens melhores." (KANT, 1992, p. 100). Para ele a Escritura não é prescindível pelo fato de que é razoável nas orientações práticas para os fiéis, devendo estes elegê-la. “(...) entre a razão e a Escritura, pode haver não somente compatibilidade, mas também unidade, de modo que aquele que se conforma a uma (sob a direção dos conceitos morais) não deixará de concordar com a outra." (KANT, 1992, p. 15). Nosso filósofo aconselha extrair das perícopes escriturísticas ordenamentos que possam tornar os homens melhores, pois, em não o fazendo, seria o que ele chama de um "aumento estéril de nosso saber histórico", simples erudição. (cf. KANT, 1992, p.40). Ou seja, não seria fecundo um estudo da teologia bíblica senão com um corte bem definido e orientador

14. Kant cumpre uma distinção sistemática entre a religião da razão (= pura, moral, natural), condicionada à "fé racional", da religião estatutária ou visível (= ritual, positiva, revelada), por seu turno condicionada à "fé histórica". (cf. KANT, 1992, p. 156). Evidentemente, desautoriza a vivência desta última (subordinada) sem o respaldo daquela primeira, uma vez que a antepõe. No que tange a tais temáticas cf. ZÖLLER, G. Credo quia rationale: Kant sobre a Fé Moral. Studia Kantiana, n. 13, p. 55-72, 2012. Ainda sobre esta temática ligada à conversão, temos em FREIRE (2005) o que segue: "O filósofo acrescenta como pressuposto para a edificação da Igreja Universal a fé pura - fé independente da fé eclesiástica, mas que se desenvolve a partir de uma fé histórica - na medida em que deve constituir-se como fé racional - fé universal porque é dada pela razão e que todos podem conhecer, todavia, ocorre que os homens dão maior valor à fé histórica, baseada em acontecimentos, leis estatutárias e numa Escritura Sagrada enquanto revelação. A primazia destes elementos acaba por afastá-los da verdadeira fé, a fé religiosa pura. A histórica - fé eclesial - na medida em que fornece a legislação estatutária da Igreja visível, deve estar à serviço da fé religiosa pura. A transição da fé histórica para a fé religiosa pura é o início a consumação do Reino de Deus. Além disso, a fé religiosa pura comunica a legislação moral pura, que deve ser a legislação da Igreja Universal e que consiste na própria vontade divina [...] o Reino de Deus configura-se enquanto uma representação simbólica que visa imprimir no homem um estímulo maior para que opere uma transformação revolução - em sua conduta moral." (p. 123). 
nas práticas do bem. Kant toma a Escritura como sendo ensinamento instrutivo, naquele sentido da Torah, um guia para o caminho. (cf. Sl 119, 105). E como se pode certificar em uma epístola de Paulo: “Toda Escritura divinamente inspirada é proveitosa para ensinar, para redarguir, para corrigir, para instruir em justiça, para que o homem de Deus seja perfeito e perfeitamente instruído em toda boa obra." (2 Tm 3, 16-17). Então, todo fiel deve toma-la em orientação, pois, “(...) tudo aquilo de que temos necessidade nos é revelado de modo suficiente (pela razão e pela Escritura) e essa revelação é igualmente inteligível para todos os homens [e não somente àqueles que se auto intitulam verdadeiros exegetas]." (KANT, 1992, p. 130).

Há uma crítica kantiana destinada aos magistrados da igreja, quando esses reservam exclusivamente a eles mesmos a autoridade para interpretar a Escritura, acreditando que o façam de maneira legítima, quando se sabe que o homem, dado o bom uso de sua razão, pode fazer sua própria hermenêutica. "A religião da razão e a ciência da Escritura são, portanto, os verdadeiros exegetas e depositários competentes de um documento sagrado." (KANT, 1992, p. 102). Kant proscreve veementemente tal atitude restritiva e, concomitantemente, despótica. Assim, ele precisa que:

\footnotetext{
(...) surgiu a terrível voz da ortodoxia na boca de exegetas pretenciosos, só eles autorizados, e dividiu o mundo cristão em partidos exasperados, com relação a opiniões religiosas (onde nenhum acordo pode ser celebrado, se não se apela para a razão pura, na qualidade de exegeta). (KANT, 2006b, p. 118, grifo do autor).
}

Consequentemente, Kant exorta ao teólogo bíblico que escute e reporte sempre ao filósofo, a fim de um melhor desempenho da ciência. (cf. KANT, 1992, p. 14). A doutrina filosófica da religião é justamente o entendimento da religião do ponto de vista filosófico, não havendo o compromisso obrigatoriamente eclesiástico-dogmático ou, se quisermos, de uma fé revelada. Desta forma, atesta Kant: "Isso não é intrometer-se nos direitos exclusivos do teólogo bíblico." (KANT, 1992, p. 16). Quando ele toma as passagens escriturísticas, o faz numa hermenêutica própria, a qual, segundo ele, deve ser a partir do entendimento de uma religião racional. "Os textos devem ser interpretados à luz de uma religião racional. Pois, se um sentido literal é prejudicial ao desenvolvimento moral do homem, então é melhor que encontremos um sentido mais apropriado à moralidade das disposições." (CAETANO, 2015, p. 91). Segundo Klein (2013), o contributo filosófico ao estudo teológico é salutar, pois mostra um novo método de interpretação escriturístico, ou seja, a partir de uma análise simbólica dos 
textos, que leve em consideração os conceitos morais, sendo justamente isso o requerimento do método kantiano. (cf. p. 178). Quanto ao mais, a escritura tem uma única e exclusiva finalidade: fazer com que o homem transforme suas práticas, impondo a si mesmo o tenaz melhoramento moral. ${ }^{15}$

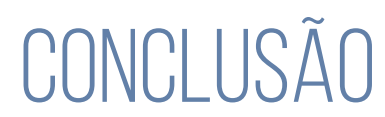

Dado o exposto, restou sumariar que, muito embora não se possa ignorar a presença do mal, toca ao homem apostar no bem e, quando suceder de desviar do princípio bom, investir de maneira incessante na reforma de caráter e no retorno a ele, o que configurará na conversão moral. Outrossim, o texto examinado A Religião, além de se inserir num estudo cuidadoso da religião, é um incitamento para que o homem engendre uma mudança em suas ações, no sentido de mudar de direção, do mal para o bem (convertio), que Kant alcunha, de forma própria, de revolução, constituindo numa instrução que atravessa o grosso de sua obra.

Pela observação dos aspectos analisados, infere-se que o mal em Kant é enfrentado de maneira positiva, sem descurar da responsabilidade do homem pelo afastamento do princípio bom, ainda que este esforço deva ser executado na coletividade (o locus apropriado). O faz admitindo a possibilidade da convertio, da mudança de pensamento e do jeito de agir, mas que por outro lado tem presente a propensão ao mal, que não pode ser negligenciada.

Enfim, a acepção kantiana de mal radical está discorrida em A Religião de maneira tal que nosso filósofo disseca a temática tendo clareza do que estava empenhado a tecer: patentear o vocativo para o respeito á lei moral, fazendo saltar aos olhos a autonomia quanto aos móbeis para o agir dos sujeitos. Perante sua interpelação poder-se-á concluir de imediato que, a despeito da natureza, a liberdade é possível, deixando firmado, neste intento, que ainda que o mal nos está posto, o bem haverá de triunfar quando o escolhermos, enquanto protagonistas e responsáveis que somos de nossas deliberações.

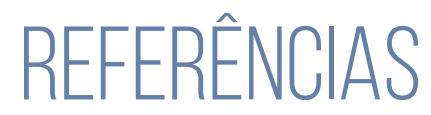

ALLISSON, H.; CARANTI, L. Libertà Transcendentale e autorità della morale in kant. Roma: Luiss Edizioni, 2000.

15. Com o propósito de uma análise sistemática do aporte moral-interpretativo que Kant estabelece com as Escrituras cf. LEMA-HINCAPIÉ, A. Kant y la Biblia. Barcelona: Anthropos, 2006. 
CAETANO, E. J. M. A filosofia da religião de Kant e aspectos de sua influência no debate contemporâneo sobre o pluralismo. Brasília, 2015. 135 p. Dissertação (Mestrado em Filosofia) - Programa de Pós Gradação em Filosofia - PPGF, UnB, 2015.

CALOVI, G. E. O Sumo Bem na ética, na religião e na filosofia política de Kant. 2008. 89 f. Dissertação (Mestrado em Filosofia)-Universidade Federal de Santa Maria, Santa Maria, 2008.

CIMINO, J. Fundamentos da Religião de Razão em Kant. 2005. 139 f. Dissertação (Mestrado em Ciências da Religião)-Universidade Federal de Juiz de Fora, Juiz de Fora, 2005.

CORREIA, A. O conceito de mal radical. Trans/Form/Ação, v. 28, n. 2, p. 83-94, 2005.

DINIS, A. A Religião nos limites da Razão. Revista Portuguesa de Filosofia, v. 49, n. 4, p. 497-509, 1993.

FREIRE, W. F. A. Ética, religião e educação em Kant. Polymatheia - Revista de Filosofia, v. 1, n. 1, p. 101-125, 2005.

GIACÓIA, O. Reflexões sobre a noção de mal radical. Studia Kantiana, v. 1, p. 183202, 1998.

KANT, I. A religião nos limites da simples razão. Tradução de Artur Morão. Lisboa: Edições 70, 1992.

KANT, I. Fundamentação da metafísica dos costumes. Tradução de Paulo Quintela. Lisboa: Edições 70, 2004.

KLEIN, J. T. Sobre Ética e Religião em Kant. Princípios, Revista de Filosofia, v. 25, n. 33, p. 161-180, 2013.

KLEMME, H. F. A liberdade do arbítrio e o domínio do mal: a doutrina de Kant do mal radical entre moral, religião e direito. Studia Kantiana, n. 15, p. 5-37, 2013.

LEMA-HINCAPIÉ, A. Kant y la Biblia. Barcelona: Anthropos, 2006.

MARTINS, E. C. R. Crusius e Kant. Revista Portuguesa de Filosofia, v. 50, n. 1/3, p. 253-260, 1994.

MUNZEL, J. F. Kant's Conception of Moral Character. Chicago: The University Press, 1999.

PAVÃO, A. Filosofia da religião e mal radical em Kant. Kant e-prints, v. 2, n. 2, p. 171-179, 2007. 
RENAUD, M. A questão do mal no livro de Kant sobre a religião. Revista Portuguesa de Filosofia, v. 49, n. 4, p. 511-535, 1993.

SPINELLI, L. M. A Religião nos limites da simples razão. Kant e-Prints, Campinas, v. 8, n. 1, p. 127-151, 2013.

SPINELLI, L. M. Kant e o Sumo Bem comunitário. Ethic@, Florianópolis, v. 11, n. 1, p. 37-57, 2012.

WEIL, E. Le mal radical, la religion et la morale. In: WEIL, E. Problèmes Kantiens. 2a. ed. ed. revista e aumentada. Paris: Vrin, 1990.

WOOD, A. W. Teologia racional, fé moral e religião. In: GUYER, Paul (Org.). Kant. Aparecida: Ideias \& Letras, 2009. (Coleção Companions \& Companions). p. 471498.

ZÖLLER, G. Credo quia rationale: Kant sobre a Fé Moral. Studia Kantiana, n. 13, p. 55-72, 2012. 